UC-NRLF

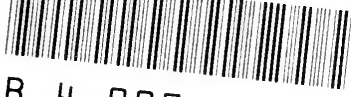

B $\begin{array}{lll}4 & 007 & 73\end{array}$ 


\section{The}

\section{Olmiversity, of Balliformia Silrony}
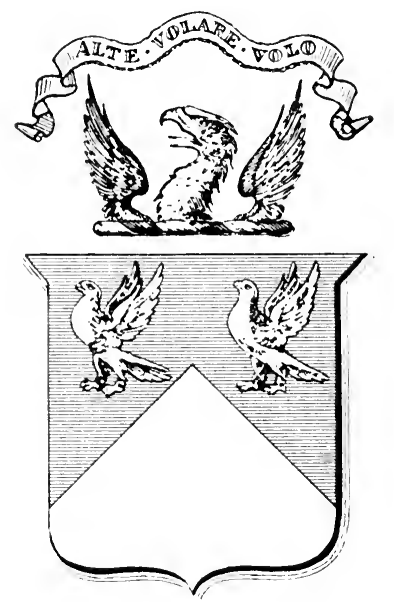

He Alorse Selphens

Onivornty of Califormin 
....

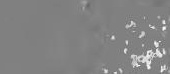

and

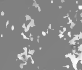

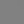

7
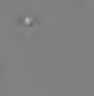


$$
\begin{aligned}
& 0^{13} \cdot 5 x \\
& x^{3} \\
& x^{4}
\end{aligned}
$$




\title{
THE BEGINNINGS OF TOWN LIFE IN THE MIDDLE AGES
}

\author{
BY \\ W. J. ASHLEY
}

REPRINTED FROM

The Quarterly Journal of Economics

Vol. X., JulY, 1896 


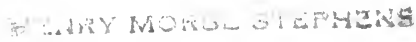

GEO. N. ELLI8, PRINTER, 141 FRANKLIN 8TREET, BOBTON. 


\section{THE BEGINNINGS OF TOWN LIFE IN THE MIDDLE AGES.}

I.

THE economist who seeks to learn something of the social history of the past is not seldom in an embarrassing situation. His first impulse, of course, is to turn to the professed historian for the information he craves; and, more particularly, when the matter is of a constitutional or legal character, to the historian of law. But, when he does so, he is only too likely to find one of two things. Either the information he receives, while it has a grammatical consistency, yet leaves him quite in the dark as to the daily life of the people concerned,- he asks for a picture and receives a formula; or, instead of one answer to his inquiry, he is given several, all from eminent authorities and absolutely irreconcilable. Then, probably, he gives up the quest, and falls back on some neat little $a$ priori theory of his own as to what the course of economic evolution must have been. If he does not, but makes up his mind to go to the original sources for himself, he will be fortunate if he escapes an occasional sly thrust from historian and lawyer for venturing beyond his last. His lot, therefore, is not altogether a happy one.

Reflections such as these will have occurred to economists who have looked of late into the subject of mediæval town history. That the towns of the Middle Ages were the homes, and the only homes, of trade and manufactures; that their rise meant the appearance of forces other than, and in large measure hostile to, those of agrarian feudalism; that their prosperity contributed nore than any other cause to the creation of the modern State and 


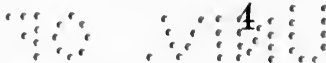

the modern gorcention of sitizenship, $;-$ all these are causes enough why' thétir históry 'shouid' be of interest. What mediæval town life was, when fully developed, say in the fifteenth century, is very evident. But how did it begin? Whence did the towns acquire their characteristic constitution, their characteristic population? And be it remarked that these two latter questions cannot, save provisionally, be kept apart. Constitutions - working constitutions, that is, not paper ones - imply corresponding social conditions. Social conditions vitally affect constitutions. The problem is one which includes constitution and conditions; as Hüllmann long ago realized when he took "Städtewesen" for his theme.*

Yet it needs but a glance into contemporary historical literature to discover that there is at present hardly any subject that occasions more animated controversy or on which competent scholars are still so far from agreement. The purpose of this article is to set forth, as impartially as may be, the present state of the discussion. Some observations will perhaps suggest themselves in the course of the exposition; but it is neither my intention to add one more to the many theories that are before the public, nor to judge them all from the standpoint of any one of the rival systems.

The reader may be spared any long account of the older "literature" of the subject; partly because I can claim but an imperfect acquaintance with it, partly because an admirably clear and fascinating statement has been recently given by $M$. Pirenne, in the first of the series of articles from his pen to which I propose to call attention. It may be said, in brief, that among German scholars, and with reference especially to German towns,- though with

* Karl Dietrich Hüllmann, Städtewesen des Mittelalters, 4 vols., Bonn, 1826-30. The example has in these later days been followed by Rudolph Sohm (Die Entstehung des deutschen Städtewesens, Leipzig, 1890), who observes "die wirtschaftliche Entwickelung steht mit der rechtlichen in untrennbarer Wechselbeziehung." 
a side glance now and again at other countries,- four views as to the origin of the municipal constitution have long struggled for the mastery. There were those who assigned primary importance to the free element in the early urban population. Thus Arnold, in 1854,* explained the constitutional history of the "free cities" of the Rhine by supposing the gradual amalgamation of the unfree households of the Rhenish bishops, over which they exercised a domanial (or manorial) jurisdiction, with a free town population, subject only to the jurisdiction of the public courts. These latter fell, he maintained, under the control of the bishops in consequence of the transfer to them by imperial grants of the right of holding the public courts, - the so-called "Ottonian privileges." The result, however, of this association of dissimilar elements under one headship was that the free ultimately predominated over the servile; and, by the time the different classes had grown into a united burgess-body, the manorial jurisdiction had altogether given way to that of the public courts. Others, on the contrary, have seen everywhere a spontaneous development out of servile conditions. Thus Nitzsch, in 1859, $\uparrow$ pictured town life as beginning in great seigneurial establishments, with hundreds of dependants (ministeriales), serving their lords in various capacities, who gradually threw aside the restrictions by which they were encumbered, and so converted manorial institutions into municipal ones. There were, in the third place, those, though few in number, who followed von Maurer from 1854 onward, $f$ in regarding the mediGotha.

*Wilhelm Arnold, Verfassungsgeschichte der deutschen Freistädte, 2 vols.,

† Karl Wilhelm Nitzsch, Ministerialität und Bürgerthum im 11. und 12. Jahrhundert, Leipzig.

† Georg von Maurer's Einleitung zur Geschichte der Mark-, Hof-, Dorf-, und Stadtverfassung, Erlangen, states in brief the conclusions for town history which he supported later by an overwhelming mass of citations in his Geschichte der Städteverfassung in Deutschland, 4 vols., Erlangen, 1869-71. 
æval town as but an outgrowth of an original free markcommunity. And, finally, there were some who laid all emphasis on free association as the real source of the later municipal system. With the shape first given to this idea by Wilda in 1831,* who traced the civic constitution to the formation of a "gild" eo nomine, none remained altogether content. But the wider formulation of Gierke, $\uparrow$ who insisted only on some sort of conscious combination the one with the other of individuals and groups previously unconnected save by propinquity, commended itself to not a few; especially as Gierke thought he could still leave room for the action of most of the other forces dwelt upon by previous writers, and so was able to give his version of town history an all-inclusive air which many found attractive. Thus Wilhelm Roscher, who, though not an original investigator of things mediæval, had a very wide acquaintance with the modern literature of the subject, wrote in 1881 :

"Primitive field-and mark-communities, the seigneurial organization (Hofverfassung) of the dependants of great ecclesiastical and secular lords, the constitution of the public courts with their Schöfen,- all these were roots of the town system. From the first two came its communal side: the third gave the town its public character. The new and creative force, however, which produced the amalgamation of all these elements, was the principle of free union (Einung) for permitted objects.... Wherever, within the same walls, a royal or episcopal subjectcommunity (Hof-gemeinde) dwelt side by side with the remnant of a free community, and the most important members of both were united in one body by the additional bond of a free union, there first could a burgessbody come into existence, such as was the result of the creation of a common law for all the town's inhabitants."

*W. E. Wilda, Das Gildenwesen im Mittelalter, Halle.

†Otto Gierke, Das deutsche Genossenschaftsrecht, 3 vols., Berlin, 1868-81. 
And, in a note, after mentioning von Maurer, Nitzsch, and Arnold, Roscher added, "The merit of having united these various one-sided theories in an accurate view of the whole belongs to Gierke." *

Roscher was apparently unaware that the school of Wilda and Gierke had just found an ally in an unexpected quarter, in the person of Nitzsch himself. In a couple of papers read before the Berlin Academy in 1879 and $1880, \uparrow$ just before his death, Nitzsch had pictured every Low-German town as dominated, during the period of struggle for municipal self-government, by a great merchant gild, containing, at first, all who had any occasion to buy or sell. Nitzsch died before he had explained the relation which existed in his own mind between his earlier and his later writings. He probably did not suppose himself to be surrendering any part of his former teaching: the comparatively new towns of the north might well have had a different history from that of the older cities on the Rhine. But his example,- commended as it was by his great reputation, especially among economists, who found something peculiarly congenial in his method of approaching history,- very naturally led to the discovery of gilds in all directions, and a fresh readiness to connect them with the beginnings of municipal government.

Meanwhile a certain affability has held back French historical scholars - as it holds back French scholars in other fields of study - from that sharp formulation of antitheses that pleases their German confrères; and partly for this reason, partly because of the smaller number of historical specialists, there has been nothing like the same diversity of opinion among them as to the early history of French towns. Putting on one side the theory of the survival of Roman municipal institutions, which - although

\footnotetext{
* Nationalökonomik des Handels und Gewerbfleisses, Stuttgart,-in 6th edition, $§ 3$, pp. 12 and 14.

$\dagger$ Ueber die niederdeutschen Genossenschaften des 12, und 13. Jahrhundert, and Ueber niederdeutsche Kaufgilden.
} 
it had a great attraction for the earlier writers and has even lately been maintained by so considerable a scholar as Glasson * - seems to have scarcely affected the view taken of the Middle Ages proper, French historical speculation has continued to follow the direction given it some sixty years ago by Thierry. This, at any rate, is the case so far as the communes of Northern France are concerned; and these have, from the first, drawn to themselves the special attention of French investigators. Thierry's view may be described as a French counterpart to that of Wilda; and it has undergone modifications not unlike those which Wilda's teaching has received at the hands of Gierke. The word "gild" has dropped into the background. It is realized, also, that the communal movement was hardly so "democratic" as was once supposed, and that it made up by no means the whole of the town history even of Northern France. Nevertheless, a view substantially similar to that of Thierry has been maintained quite lately by Giry, the author of two most important monographs (on the history of Saint-Omer and SaintQuentin $\dagger$ ), and the inspirer of many more, and by Luchaire, the most eminent of the historians of the Capetian centuries. The extreme caution of M. Luchaire in certain directions, as exemplified in his Communes Françaises (1890), adds but the more weight to his judgment. The question of "origins" he regards as "insoluble." $\ddagger$ There is a complete hiatus in our documents, apparently never to be filled up, between the seventh century and the eleventh. Nevertheless, he has no doubt that "the creative element of the commune," that which produced the mediæval town, with its distinctive government and separate jurisdiction, out of "collections of traders and arti-

* See hereon M. Flach's chapter on Les Théories Générales in his Origines de l'Ancienne France, ii. 215 and 216, note 3.

$\dagger$ Histoire de la Ville de Saint-Omer, Paris, 1877, and Etude sur les Origines de la Commune de Saint-Quentin, Saint-Quentin, 1887.

$\ddagger$ Page 11. 
sans, all of more or less servile condition," * was "the association of inhabitants formed under the guarantee of a mutual oath," $\dagger$ - an association which succeeded in obtaining from the lord of the town, by violence or negotiation, the franchises it was formed to secure. He goes further: he recognizes a "community" - a sense of joint interests and the practice of acting together - "before the commune." How this was organized, what were its relations to serfdom, whether the common lands of such communities were owned, or merely used, in common,again he will not venture to say. Here reigns an obscurity "which will doubtless remain impenetrable." $\ddagger$ Nevertheless, he believes that among the members of this body slowly becoming aware of its community of interests there often grew up partial societies, mercantile and religious gilds and fraternities; and that these "partial associations became the germ and the prototype of the general federation" $\$$ which constituted the commune. In some, indeed, and these important cases, "the merchant association" was itself "directly transformed into the municipal"; and the commune and the gild merchant were in such places for some time identical.\|

II.

There were thus, in Germany and in France, theories enough and to spare. But the period of the seventies and the eighties was, in both countries, a period of town monographs rather than of general views. The new period of animated discussion in the midst of which we now live was opened by a series of remarkable articles and pamphlets by Georg von Below (first of Königsberg

* Page 29.

$\dagger$ Page 26.

$\ddagger$ Page 38.

§ Page $26 . \quad \|$ Page 32. 
and afterwards of Münster), beginning in 1887.* With extraordinary clearness, vehemence, and occasional scurrility, von Below urged that the only satisfactory explanation of early German town history was, after all, to be found in the theory of von Maurer,-a theory, as he remarks, now "almost under the ban." $\dagger \mathrm{He}$ makes, indeed, a change of more significance than he realizes in his method of formulating it. Without indicating any dissatisfaction with "the mark-theory" itself, von Below prefers to start with the village as we actually find it in the Middle Ages proper, and to leave untouched the question of the historical relation of the village to its lord.f Instead of a Markgenossenschaft he prefers to speak of a Bauerschaft, a peasant group, or, more commonly, of a Landgemeinde, a term untranslatable, but which we may render by "rural township," or "rural commune" in the modern French sense of the word "commune." The German town-community is, he declares, the daughter of a country commune; the town magistracy and municipal organization but developments, with amplified functions, from the old village magistracy and organization. He grants that the town was more than the village, and he allows that it was the growth of trade which brought about the change; but he maintains that there was never any breach in the continuity of institutions, and that the later town government was a natural growth from germs present from the first in the rural township: it owed nothing fundamental to the public courts of the hundred, or to seigneurial establishments, or to mercantile gilds.

In Germany the result of von Below's appearance in the field was amusingly unexpected, and very different

* Of these the most important are two articles Zur Entstehung der deutschen Stadtverfassung in the Historische Zeitschrift, lviii., lix.; Die Entstehung der deutschen Stadtgemeinde, Düsseldorf, 1889; and Der Ursprung der deutschen Stadtverfassung, Düsseldorf, 1892.

† Stadtgemeinde, 1.

$\ddagger$ Ibid., 3, note 2 ; Stadtverfassung, 23, note 1 . 
from what von Below himself anticipated. In 1890 came forth a little pamphlet of a hundred pages, bearing the honored name of Rudolph Sohm,* which changed the whole situation. He began by attributing to von Below the merit of raising anew fundamental questions. $\mathrm{He}$ went further, and credited him with having absolutely disproved both the seigneurial view of Nitzsch and the Ottonian-privileges view of Arnold. But on the ground thus cleared he refused to build in the manner of von Maurer. With von Below's positive views, he asserts, it is impossible to agree. On the contrary, he turns into an altogether different path, suggested by two contemporary historical essays, to which he now called particular attention. Schröder's papers on the Weichbild - a mediæval term for a town and its constitution, which Schröder explained as originally meaning "town emblem," and identified with the market-cross - had "proved the identity of market-law and town-law, of market-court and towncourt." $\dagger$ Another scholar, Schulte, with the aid of a hitherto unprinted charter of Radolfzell of the year 1100 , had demonstrated the truth of this proposition in particular cases and had further made it clear that "town-law grew out of market-law." $\ddagger$ Other factors may have contributed to the result; but the decisive factor was the market with its law. "Within the merchant class differences of birth disappeared; and out of this market-community, which knew only of differences of occupation and wealth, arose the town administration, the original model of our modern national administration." But now what was the market-law? It was originally, and in the main, a code of heavier penalties for breach of the peace than were inflicted elsewhere. In the language of the period, it was a special "peace." And this special peace Sohm goes on to explain (and this is his own contribution) as

* Die Entstehung des deutschen Städtewesens. Eine Festschrift. Leipzig.

† Page 14.

$\ddagger$ Page 15 . 
constructively the peace of the king's house or fortified residence, his Burg. Such a peace was, we know, maintained in the king's house in Frankish times. And in after ages, Sohm maintains, whether a place was fortified or not, the grant of Burgrecht or Weichbildrecht meant the recognition of it as a place specially subject to the king, under his special protection, the contempt of which involved peculiarly heavy penalties. Such an exceptional position necessarily involved the creation of a special tribunal; and hence the market-court.

The effect of Sohm's book has, however, not been so much to secure acceptance for his particular explanation of the genesis of market-law, as to commend, with all the weight of his authority, the general view that it was out of market-privileges, in some way or other, that town government proceeded. In spite of the forcible arguments of von Below, ${ }^{*}$ the market-theory has since been very widely welcomed, especially by jurists.

Sohm had spoken in general terms of Kaufmannschaft (body of merchants) and Marktgemeinde (market-community). It wanted but little to suggest to subsequent writers a connection between this body and the merchantgild which had played so considerable a part in earlier discussions. But just at this time appeared the treatises of Hegel and Gross, which were at once pretty generally acknowledged as decisive on one of the most important of the old issues. Gross's Gild Merchant $\dagger$ is limited in its scope to England. But England had been often regarded as the peculiar home of gilds. It had furnished some of the most frequently quoted evidence for a direct influence of the gild on the civic constitution. Accordingly, the apparent demonstration that the gild and the burgess-body were always distinct, and that the gild

* Ursprung der deutschen Stadtverfassung, passim, and especially p. 11 et seq.

† Charles Gross, The Gild Merchant: A Contribution to British Municipal History, 2 vols., Oxford, 1890. 
merchant had no influence on the origin of the municipal constitution in England, could not fail to react on German opinion as to German towns. This was all the more likely to be the case, since his results agreed in the main with those simultaneously reached by Hegel, ${ }^{*}$ after an investigation covering the whole range of the Teutonic and Scandinavian world. Hegel took occasion, it may be noticed, to oppose the most complete denial to Nitzsch's theory as to the evolution of the craft gilds out of an original all-embracing merchant gild.

Into the minutiæ of the discussion which was immediately excited by these writings of von Below and Sohm, of Hegel and Gross, it would be wearisome to enter. Innumerable have been the essays that have appeared dealing with some particular point, such as Weichbild, or burgage-tenure, or the regulation of weights and measures, or with the history of particular towns or groups of towns. $f$ What will interest us more are the attempts which, after three or four years of such discussion, certain scholars are now making to take a survey of the whole field, and once more to set about a work of construction which shall assign to each element its proper place in the completed structure. Four such attempts stand out from the rest for the distinction of their authors or the thoroughness of the performance; and this article will be mainly occupied with a statement and comparison of their conclusions. They are, arranged in order of time: (1) the section on La Commune Urbaine in M. Jacques Flach's Origines de l'Ancienne France; $\ddagger$ (2) three articles Zur Entstehung der deutschen Stadtverfassung, by Dr. Willi

* Karl Hegel, Städte und Gilden des germanischen Völker im Mittelalter, 2 vols., Leipzig, 1891.

$\dagger$ Long lists will be found in several places; e.g., at the beginning of Varges' articles, to be shortly referred to, and in Richard Schröder's Lelirbuch der deutschen Rechtsgeschichte (2d ed.), 600.

$\ddagger$ Vol. ii., 1893. The subject occupies 213 pages, or, with the chapters on la sauveté which precede, 254 pages. 
Varges in Conrad's Jahrbücher für Nationalökonomie; * (3) three articles on L'Origine des Constitutions Urbaines au Moyen Age, by M. H. Pirenne in the Revue Historique; $\dagger$ and (4) Untersuchungen über den Ursprung der deutschen Stadtverfassung, by Dr. F. Keutgen. $\neq$ Of these, M. Flach concerns himself only with France; but he recognizes that "the points of comparison and contact, especially in the east of France, between the development of municipal government in France and Germany are so numerous" that a French scholar cannot afford to disregard what has been done elsewhere. And, as his preliminary survey of "general theories" shows, he writes with a constant recollection of German doctrines. Dr. Varges and Dr. Keutgen limit their range to Germany; and the latter declares that this limitation is one of principle as well as of convenience, on account of the essential difference between the course of affairs in German and Romance lands.§ M. Pirenne alone seeks to include both France and Germany in one view, and justifies this procedure by considerations capable of even wider application than he himself makes of them.\|

*In the parts for August 31, 1893 ; December 22, 1894 ; and April 30, 1895, -in all, 156 pages.

$\dagger$ In the parts for September, 1893, and January and March, 1895,-in all, 109 pages.

$\ddagger$ Leipzig, 1895, 236 pages.

§"Man mag einzelne Erscheinungen zum Vergleich heranziehen, aber eine so vollkommene Gleichheit auch durch das fränkische Recht auf einem Teile des deutschen und des französischen Gebiets hergestellt worden sein mag, so wäre es doch verfehlt, für die Verfassungsgeschichte diesen Bezirk als Einheit zu nehmen. . . . In allgemeinen ist daran festzuhalten, dass die Ausgangs. punkte für die Verfassung auf deutschem und auf romanischem Gebiete wesentlich verschiedene waren. Und trotz aller Parallelen die sich ziehen liessen, hat sich diese Verschiedenheit später bewährt." (p. 7.)

|| "Le problème a été généralement envisagé à un point de vue trop étroitement national. Si, comme la féodalité ou le socialisme contemporain, les villes du moyen âge sont avant tout le produit de certains causes économiques et sociales, il faut, ce semble, les étudier sans tenir compte des frontières politiques. De même qu'on ne distingue pas une féodalité française et une féodalité allemande, de même aussi il n'y a pas lieu d'établir une ligne de dé- 


\section{III.}

M. Flach divides French towns into two classes: the "ancient" or "old" cities, or, more strictly, those arising from "a regeneration and remoulding" of ancient (Roman) cities; and the "new" towns, which owed their birth entirely to the Middle Ages.* And, first, as to the former of these two classes. No mistake can be greater, he thinks, than to suppose that the Gallo-Roman cities passed through the mediæval centuries undergoing nothing but a slow and gradual modification of their peculiar institutions. All of them were well-nigh ruined by the barbarian invasions and the wars that followed: and, to retain any fragment of their old civic life, their inhabitants were compelled to gather more closely together, and to fortify, with the debris of old walls lying round on every side, a small portion of what had once been the city area. This contracted and reconstructed fragment of the old Roman city was the castrum or civitas (cité) of our early mediæval documents. Within it, upon rising ground, or with its back upon the city wall, commonly rose a citadel, a castellum, arx, maxima turris, château, or castrum (in a narrower sense of the term) ; and outside it, grew up by degrees, in the eleventh century and afterwards, one or more bourgs, usually around some religious house. "The unity of the ancient city was broken, and with it all real continuity. The later town was not the natural descendant of the old city. It could not come into existence until a new unification had taken place,

marcation entre les villes allemandes et les villes françaises. . . . Les causes profondes des origines du mouvement sont les mêmes dans les deux parties de la Francia. Dans les bassins de la Seine et du Rhin, l'organisation primitive des villes présente les mêmes caractères essentiels." Revue Historique, liii. 82.

*This distinction between "les villes antiques" (p. 301), or "les vieilles cités" (p. 304), and "les villes nouvelles" is not always kept in the forefront; but it dominates M. Flach's whole argument. 
and until groups of population hitherto different in character and merely juxtaposed " (i.e., those of the chatteau, the cité, and the bourgs) "were blended and assimilated as the result of being enclosed within the same walls." *

But in the eleventh century this unity had still to be created; and meantime the physical severance of the various parts of what, by anticipation, we may call the "town," was paralleled and surpassed by the partition of authority over its inhabitants. The Frankish policy of exercising public authority by means of comites, or counts ; the Carlovingian policy of relying upon and favoring the bishops; the tendency for public offices to become fiefs; the necessity under which the bishops lay of securing the assistance of advocati, avoués, Vögte; the grant of ecclesiastical and lay immunities; the practice among the great lords of appointing representatives to exercise their authority (vicedomini, vidâmes); the almost endless delegation, reservation, and subdivision of rights both of property and of jurisdiction, - all these led to an extreme fractionnement of authority, and brought it about that, while most towns had certain large features in common, the details of their government differed in almost endless variety. Thus at Amiens there existed, side by side, a count and a bishop, a vidâme and a vicomte, a châtelain and an avoué. To make the confusion worse, most of these had their own executive officers, - the vicarii or viguiers, the prepositi or prevôts, and the like, one or more. The jurisdiction exercised by these various seigneurs and

* In Book III., chap. iii., M. Flach lays down the general proposition as to "la distinction entre la cité, le bourg, et le château" (p. 250); and in chap. iv. he supports it by the instances set forth at length of Rouen, Tours, Bourges, Nevers, Périgueux, Albi, Toulouse, Béziers, Nîmes, Montpellier, Narbonne, and Carcasonne. Cf. Mistral, Dictionnaire Provençal Francais, s. v. Bourg: "La plupart des villes du Midi, Arles, Digue, Castellane, Carcasonne, Narbonne, Toulouse, Rodez, etc., se divisaient au moyen âge en deux parties, la ciéuta et lou bourg. La ciéuta, la cité, était l'ancienne ville, généralement entourée de murs; le bourg, formé de maisons élevées peu à peu en dehors de l'enceinte, était séparé de la cité par un certain espace; tandis que la bourgado (faubourg) était attenante aux murs." 
officials was, in theory, clearly distinguishable as either public or private; but, in practice, the line was not easy to draw. Most great lords exercised at the same time a jurisdiction in its origin public, and a jurisdiction in its origin pruthic over different persons, or over the same persons in different capacities. In many towns there were, in addition, a number of little fortresses inhabited by knights or even by wealthy merchants, each claiming all the jurisdiction he could get over his handful of retainers or tenants. In these respects there is no conspicuous difference between France and Western Germany; and any attempt to draw a sharp contrast - as that in France the secular authority of the bishops rested on immunities, while on the Rhine it rested on grants of county jurisdiction - is defeated by the evidence.*

So much for " the old towns." As they grew up around the cité, so most of "the new towns" grew up around a castle or a religious house. The castle brought people together in various ways. Homes were needed for its soldiers' families, and for the artisans who supplied their wants. The castle chapel served as a parish church. The market, which the lord's interest in cheap provisions led him to establish, attracted traders; and the walls gave protection to refugees from justice or tyranny. That such agglomerations frequently became towns is shown by the number of town names partially composed of such words as château, châtel, châtillon, ferté, roche, etc. In such towns authority was more likely to be held in a single hand tham in the old cities; though it was common enough for one or more ecclesiastical bourgs to grow up outside.

Monasteries and cathedrals still more frequently served as nuclei for town-formation. Their walls were almost as sure a protection as those of a castle. They needed an equally large body of servants, though some of them were of a different kind. To such as gained a fime for

* Pages 281-285. On the identity of the châtelain and Burggraf, see p. 294. 
miracle-working relics, first pilgrims came, then traders, then artisans, - just as to a famous shrine to-day. Very commonly the close enjoyed the right of asylum. Sometimes the right was extended to an area large enough to contain a whole bourg, - "a sauveté, properly so called"; and, where that was the case, there was likely to be a continual influx of the distressed and the ruffianly.

M. Flach is the first writer, so far as I know, to assign to the sauveté (salvitas, salva terra)-equivalent apparently to the English sanctuary* - a part in the creation of the mediæval city constitution. For his view, set forth at length, we must turn to earlier chapters of the book. He there seeks to show how the sanctuary originated in religious reverence; how it received the recognition of the secular authorities by a distinct surrender of their jurisdiction; and how complete immunity from external claims was balanced by complete subjection to the sanctuary's lord. The relation between sanctuary and town is illustrated by Chapelle Aude in Berry. In 1058 a local seigneur gave certain lands and dues there to the great abbey of St. Denis. Thereupon a priory was founded; but, to obtain a population for the town the monks wished to create, a sauveté had to be established. Four wooden crosses were set up at the corners of a tract of land large enough to hold a bourg (and including something more than the lands which had become the property of the abbey); and King Philip I., with the assent of his lords, granted to the tract so marked out complete freedom from external jurisdiction, from toll, and from military service. Fortunately, we possess a charter granted in the year 1073 by the prior to what were already called the "burgenses" of the "villa," from which we learn that the charges levied upon the inhabitants in return for the advantages thus bestowed were already fixed by mutual understand-

* As in the cases of Hexham, Ripon, Beverley, Durham, Beaulieu, Westminster, and St. Martin's le Grand in London. 
ing. This charter reveals, moreover, the germs of a communal militia in the article which binds every burgess to march out under the prior to ward off tyrannical assaults; as well as the idea of a communal treasury in the article obliging the burgesses to maintain, at their common expense, such great personages as might visit the town for its common benefit. It is thus, says M. Flach, a precursor of the communal charters, and it is isolated only because our material is defective. "Nothing could show more clearly the position of the sauveté as a historic link between the mere village group and the urban commune." *

But the rise of new towns was not due in every case to the presence of a castle or religious house. Villages occupying peculiarly favorable situations sometimes grew into towns. "Yet mere increase in size was not sufficient to transform them into towns. For that it needed the conjunction of several propitious circumstances. In my opinion, three principal elements distinguish towns from villages: a material protection, resulting from the presence of considerable fortifications; a religious protection, secured by the residence of a bishop, the presence of a church possessing venerated relics or of a monastery belonging to a powerful order; and commercial activity, shown by the holding of at least a weekly market." $\dagger$ The absence of any one of these three might suffice to balk the fairest hopes. M. Flach cannot agree with thoseas, for instance, Hegel - who believe that mere fortification by wall and rampart was not essential to a town's being; that the vital element was the possession of a court of its own (ein eximiertes Stadtgericht). The "ancient" towns survived, though they enjoyed no such franchise; and, on the other hand, many places that had received that franchise never succeeded in really becoming towns.

* Page 202.

† Page 329. Cf. p. 341: "Les divers éléments que nous considérons comme organiques, élément religieux, commercial, militaire." 
The earliest transformations of villages into towns go back, as in the case of Bruges, to the invasions of the pinth and tenth centuries, and the building of walls which these occasioned. Oppidum itself commonly meant such a fortified place; and to fortify a village and "erect an oppidum" were synonymous expressions. The new prospect of security usually led in no long time to the appearance of the other elements necessary to make a town; and, as the seigneurs of such villages (always subject to some lord or other) were usually glad to encourage a conflux of residents for the sake alike of the revenue and the military strength they brought, they were ready to assist the process by the grant of liberties,- especially the rights of free alienation of land, and of trial in all matters, civil and criminal, before town échevins. The advantages which a lord could derive from his authority over a town were so considerable that a lord would now and again set about the creation of a town by the proffer of privileges to all comers. Such attempts illustrate the close connection between the progress of municipal liberties and the self-interest of the seigneurs; but it must be added that they were rare, and still more rarely successful.

Nor must the fair words of charters deceive us as to the real position of affairs in all towns, whatever their origin. The lord's castle at all times held the town at his mercy. Arbitrary authority lay behind all his relations to the townsfolk. Hence it was that the destruction of the castle was the first desire of the young communes and the necessary prerequisite for any real liberation. The monastery - weaker, as a rule, in the arm of flesh - was supported by the religious sanctions it could invoke. And, whether the lords were lay or clerical, the resistance of the people was weakened by differences of status, by divergence of interests, by dependence on different lords, by the tendency to make common cause with one's own lord 
against all outsiders, and by the prevalence of "personal" law.

Nevertheless, forces were already at work tending towards unity. In a chapter on "la formation du lien corporatif," M. Flach sets forth the ways in which divers groups within the town acquired a sense of corporate life. These groups he conceives of as the "cellules" out of which the later municipality was to grow. Which of them should serve as the nucleus for the others to gather around depended altogether on their relative vitality and vigor.

There was first the link of common material interests. The castrum may have inherited some fragments of the communal property of the old Roman city; the village which had grown into a town retained its old rights of common. Then there was the tie created by the common possession of those privileges of asylum which the townsfolk frequently enjoyed. This asylum might be an extension to the whole town of the special advantages of the royal palace; but cases so explicable were very exceptional, and all such went back to a special grant, and were by no means the offspring of a mere legal fiction (as Sohm would have it). The real source of town asylum, as a rule, was the sauveté already described. The cross was its symbol, and had originally nothing to do with the market (as Sohm and others maintain). On the contrary, it was the asylum which really gave security to the frequenters of the market: the special market-place was limited in duration to the market hours, and there is no trace of its extension.

But there were even closer bonds of union, and three in particular, - the tie of caste, of religion, and of industry.*

As to caste. At the head of the town population were the chevaliers, serving the lord (or lords) of the town, and usually holding $\not \mathfrak{d}$ fortified house within it and extensive 
domains outside. Next to them was "the class of free men, the bourgeois proper." They were marked out by the right to answer only before magistrates appointed from among themselves and representing the old public justice of pre-feudal times, - to wit, the échevins; a fact not peculiar to the north of the country, though that special designation might be. As the number of these "free burghers" could be added to by enfranchisement, one might suppose that it would be the échevinage which would serve as a centre for all the non-military (roturière) population to attach themselves to. But such an outcome was rare. Usually the burghers (or the richer among them) and the chevaliers drew together, made common cause, and monopolized the town magistracy, - an alliance facilitated by the position of the intermediate class of ministeriales. When the communal movement began, it was this urban patriciate which placed itself at the head, and reaped the harvest.

Among the lower people - the minores, plebs, vulgusthe most effective bond of union was the parish. The parish created local groups, with a strong corporate sense, out of disconnected dependants of rival lords. And within the parishes grew up the even closer associations of religious gilds, fraternities, "charities," with mutual assistance in the redress of wrong and the support of the unfortunate, and common obedience to chosen officers. Analogous results were reached by the merchant and craft gilds. All these fraternities, professional and non-professional, may be regarded as going back to three sources, - Roman (for M. Flach thinks it probable that the tradition of the Roman collegia never wholly died out), Germanic (marked especially by the mutual oath), and Christian.

Various corporate groups had thus come into existence. Here a patrician, there a plebeian, association showed most vigor; and, when the moment came, this association put itself forward, gathered around itself the rest of the popu- 
lation, impressed upon it its own stamp of a sworn brotherhood, and, lo! the sworn "commune." The token of their success was the acquisition of a charter, by force or by bargain ; and this charter, conferring as it did rights on the whole body of inhabitants, gave them new and strong common interests. Not that they had never possessed any common interests before. M. Flach repeats that the sauveté and the immunité had sometimes served this purpose. In other cases the parochial machinery was strong enough to serve the purposes of municipal administration.

Where there were no such institutions or none strong enough, the preliminary task of binding together the town population might be accomplished by an institution de paix, - a voluntary association to maintain the peace,- - or by an amitié or town gild. But, whatever unifying forces had previously been at work, it was the sworn confederation of diverse social elements which formed the really original feature in the new communes. The violence of the communal movement in the north of France was the consequence of race traits reacting against a harsh seigneurial rule. The comparative quietness of a transition substantially similar to it in the south may be explained by a gentler rule over a milder people. The general results, however, were much the same. The divergencies in detail, indeed, between the several constitutions were so great, and the number of possible combinations of particular features so large, that it is very difficult to classify them. Still, the town charters may be roughly arranged in three groups: (1) those granted to sworn communes, whose main significance lay in the recognition of an already existing "urban association"; (2) the charters of customs, regulating the obligations of the inhabitants towards the lord, with little reference to municipal organization; and (3) the charters of franchise, based indirectly on sauvetés, directly on institutions de paix and brother- 
hoods, and settling at the same time the form of government and the amount of dues.

As this outline of M. Flach's chapters may have shown, the lucidity which marks the earlier stages of the exposition is hardly maintained in the later. It becomes not infrequently difficult to discern M. Flach's real meaning; and $I$. cannot be at all sure that $I$ have not misrepresented him. As he proceeds, he loses control of his material; until in the last three chapters the several factors of the town constitution not only fail to be put into any distinctly intelligible relation to one another, they are hardly even disentangled. The final impression of the communal movement which he creates seems to be not at all unlike that already traditional with French writers, and stated but shortly before by M. Luchaire. The agreement between M. Flach and M. Luchaire is especially close in regard to the relation of the fraternities and gilds to the sworn commune: what with the latter are "germs," constituting "a community before the commune," are with the former "cellules," forming a "lien corporatif" before the "lien communal." What we have chiefly to thank him for is the attempt to picture to us the urban "agglomeration" of the early Middle Ages, and to bridge over the gulf between that and the Roman city whose site it occupied. He succeeds in making us feel how complex was the development which lay at the back of the communal movement itself, and the multiplicity of the factors which have to be taken into account in towns of any magnitude. He certainly produces in the reader - and this is no small thing - a frame of mind indisposed to hastily accept any large and sweeping theory.

On looking back over his examples one cannot fail to be struck by the fact that the "ancient cities" include the great majority of the important towns of mediæval France. And the probability presents itself,-which 
would need to be tested by a more strictly chronological arrangement of the material than we find with $\mathrm{M}$. Flach, - that the development of the new towns took place under the influence of conceptions of citizenship to which the history of the older towns had already given birth.

We may single out from his account of each class of towns one feature as calling for special notice. With the old cities it is the relation of the bourg to the cité, and their subsequent union. That the situation was as he describes it seems abundantly proved for Central and Southern France; and there were, as we shall see, precisely analogous cases in Germany and elsewhere. But the use of the term bourg raises some difficult questions to which we shall return later.*

As to the new towns, M. Flach, as before remarked, puts forward what looks like a fresh view, in the importance ascribed to the sauveté. But it must be said that he does not make it quite clear what the sauveté was. In one place, he remarks incidentally that the sawvete was "only an application of the Trueo of God"; $\dagger$ and he throughout carefully distinguishes it from an immunity. $f$ Yet in the examples he produces the sauvete looks remarkably like an immunity, but an immunity for which reasons were given peculiarly appropriate in a grant to a religious body in times of violence. And M. Flach does not make it clear that the sauveté, eo nomine, was an important factor in the development of any town of importance.

* See infra, p. 287, note.

† Page 391 .

$\ddagger$ Page 365 . 
IV.

Dr. Willi Varges's articles on the origin of the constitution of German towns, to which we turn next, differ in their composition as widely as they well could from the chapters of $M$. Flach. They make no effort after a pleasant style; the argument is arranged with the utmost formality; each paragraph opens with a proposition, and then goes on for a page or more to furnish the proof. While M. Flach refers only to original authorities, Dr. Varges freely employs the modern literature of the subject side by side with the sources, and has no hesitation in borrowing his references. His own studies have apparently been directed to the North-German towns, especially Brunswick; but his conclusions are stated as if valid for the whole of Germany. They are as follows :-

Towns have commonly grown out of villages; but, when fully grown, they are marked off from villages by four characteristics. Towns are fortified (befestigt); they enjoy a special ofuge (befriedet); they possess the right of trade (Verkehrsrecht: usus negotiandi, usus mercatorius, potestas mercandi, mercatus), mistakenly explained as mere market-rights; they are corporations of public law, exempted from the jurisdiction of the Gau, and possessing rights equal to those of the Gau. And so the inhabitants are defenders of their stronghold, their Burg, and hence burgenses, burgesses; they enjoy a higher protection than villagers; they have the right at all times to carry on trade in the town, and hence are mercatores, merchants or traders; and they form a community with a court of their own (bilden eine eigene Gerichtsgemeinde), and live under a town-law of their own creation.*

1. The town as a stronghold (Festung). This was at first its most important characteristic : as the early use of

* Jahrbücher für Nationalökonomie, lxi. (F. 3, B. vi.) 164. 
Burg for town, not replaced by Stadt till after 1100, and the terms burgensis and Burger, clearly indicate. The works of defence consisted of a circuit of walls (at first merely of earth or timber), and usually a moat: a group of houses which merely lay under or near a castle was not a town. As the right to fortify was a royal prerogative (Regal), the towns were originally royal fortresses. Hence the first inhabitants are to be regarded as "a standing garrison": not, indeed, that they were professional troops,- they were merely members of the nation to whom had clung the old obligation of military service once resting on the whole people.* Indeed, the burghers and the knights formed the two branches of the new military system, now taking the place of the old: the former did garrison duty, the latter served in the field. And the functionary who first appears as exercising authority in the town, under whatever name,-profectus, Vogt, Burggraf - is primarily a Constable or Captain of the Castle.

2. The town as a place enjoying a special peace (Friedeort). The exceptional peace (or Bann) which prevailed in the town, involving the punishment of criminal offences committed there by exceptionally severe penalties, was the king's peace; and the Weichbild, or town emblem, was its peculiar sign. And here Dr. Varges puts forward what is, so far as I know, a quite original explanation of the origin of the town peace; namely, that it is nothing more nor less than the primitive peace of the national army (Heerbannfriede), specialized for the benefit of a standing garrison. Towns, he repeats, were at first essentially mil-

* Ibid., p. 175 : “In den Stadtbewohnern, den Bürgern, hat sich ein Rest des alten Volksheeres erhalten," following von Maurer, i. 485, note: "Der Kriegsdienst der Bürger war immer noch der alte Königsdienst." In this connection it is usual to cite the passage of Witukind, describing how Henry $I$. (the Fowler) selected one out of every nine of the "agrarii nilites" to dwell in the strong places (urbes) he had erected. This term is very variously interpreted: by Waitz and Giesebrecht as "königliche Ministerialen," by Varges as "wehrhaftige, heerpflichtige Dorfbewohner," and by Keutgen by what is the same, "heerbannpflichtige Bauern." 
itary in their character. They were nothing but fortified villages, whose inhabitants, though peasants engaged in agriculture, were subject to special military obligations, and therefore enjoyed a special protection. Trade was carried on only in unusually favorable situations, and then chiefly by foreigners and Jews.

3. The town as a place of trade. As time went on, the characteristics of the town altogether changed. The fact of trade and the right to trade became all-important. The right to trade rested on a grant by the king, or other lord, of the potestas mercandi or mercatus. Such grants were not originally bestowed only on towns: they were sometimes given to religious houses or villages. The modern terms Markt, market, are of course derived from mercatus; but it is altogether a mistake to limit the meaning of mercatus to the right to hold a market,-Dr. Varges's most original contribution to the discussion. The general right to trade had nothing necessarily to do with markets, which, on the contrary, interfered with it; and markets really played a very subordinate part in the building up of the town constitution. All burghers settled in the town could, if they chose, take part in trade; and there was no merchant gild monopoly.

4. The town as a community of public law. Without its own court and its own law the town was not complete. The appearance of the court was the consequence of the growth of a peculiar town-law; and this town-law was not the outcome of a merchant-law (itself perhaps growing out of a special-king's law), as Sohm and others maintain, but simply the common law of the country modified by new economic needs, and varying widely from place to place. Townsfolk had long been marked off from countryfolk by the town walls, by the special peace, by the obligation of watch and ward. The contrast was now heightened by the activity of trade. At the same time the construction of a peculiar town-law necessarily led to the 
establishment of a separate tribunal ; and this might come about in any one of several ways, - by the transformation of a county court (Grafschaftsgericht), by the addition of authority to an assembly of peasants, or by the establishment of a brand-new court.

And now the burgher body, the Stadtgemeinde, what was it? As a rule, nothing but an enlargement and modification of a Landgemeinde, a village group. The enlargement was brought about in several ways, especially by the union of several neighboring Ortsgemeinden ("synoikismus"), and by a stream of immigration the volume and effect of which can hardly be exaggerated. An elaborate, and not very convincing, argument follows, as to the legal facility of emigration from the rural lordships.

Burgess rights were bound up with the possession of land or house within the town. But to obtain house or land was not difficult, and it was early facilitated by the institution of Wortzins. In most of the towns, especially the older ones, the land was not the absolute property of citizens : it was held of a lord, but on very beneficial terms. The holding was burdened only by a fixed money rent (becoming nominal in course of time), and it was freely alienable and heritable.

At first the craftsmen were as much citizens as the merchants. Not till later, usually after the establishment of a town council at the beginning of the thirteenth century, did the larger landholders and the "merchants" in the modern sense form a patriciate monopolizing the government. In earlier times mercator designated the craftsman as well as the mere trader.

The foregoing abstract will have shown that, as M. Flach substantially follows Luchaire and Giry, so Dr. Varges bases his construction on von Below and von Maurer. The two new features which call for notice are the doctrine of the Burg and the doctrine of the mercatus. 
As to the Burg, it will be seen, on looking up the references candidly supplied by Dr. Varges, that the idea of the importance of the fortifications - an importance so great that they furnished the chief external trait of the mediæval town - had already been forcibly expressed and supported with abundant learning by von Maurer.* Bücher, $f$ and probably other writers, had described the burghers as a standing garrison. What is new with Varges would seem to be the consequence drawn from his garrison theory as to the genesis of the town-peace. That Burg meant a place of defence, that the oldest "towns" were in some way connected with defence, we can hardly doubt. It is well known, also, that in the later Middle Ages towns on the continent of Europe were commonly surrounded by walls and moat. But it is by no means clear to my mind that we are to think of the earlier Burgen as walled towns. The "burhs" which Edward the Elder and his sister Ethelfleda were building in Mercia at the very time that Henry the Fowler was building his Burgen in Saxony are usually described,- and the description seems to be justified by existing remains, - as earthen mounds, surmounted by brick citadels or wooden stockades. $f$ This

* Städteverfassung, i. 103.

† In a lecture given in October, 1890, entitled Die Entstehung der Volkswirthschaft, and printed in the volume bearing that name in 1893, p. 45: "Die mittelalterliehe Stadt ist in erster Linie eine Burg, d.h. ein mit Manern und Gräben befestigter Ort. . . . Anfangs sind die dauernden Bewohner der Stadt auch hinsichtlich ihrer Beschäftigung in keiner Weise von den Bewohnern der Landorte unterschieden.... Aber ihr Gemeindeleben erschöpft sich nicht in der Regelung der Allmendnutzung. . . . Sie sind ja sozusagen als eine stehende Besatzung in die Burg gelegt." This view Bücher associates with the further theory that the existence of a town implied the formation of a protective association (Schutzverband) among the rural settlements of a more or less considerable area around, all of whose inhabitants were bound to keep up the fortifications, and take part in their defence. In return, they had the right to take refuge (zu bergen) behind the walls, with wife and child, cattle and goods. "This right is called Burgrecht, and he who enjoys it is a Birger!"

$\ddagger$ English Chronicle, s. a. 913. Hereon see Green, Conquest of England, 198 et seq.; Boase, Oxford, 3. 
might be an equally true description of the German Burg. M. Flach has shown us how from the cluster of cabins around and beneath the citadel of a lord towns might and did sometimes come into existence in France; and there seems no reason why the same should not be true of Germany. The people defended by, and, if need were, taking part in the defence of a Burg, a Burh, might naturally enough be called Burgliudi (=Burgleute), or, in AngloSaxon, Buruh-waru, long before they themselves were girdled around by a wall. Dr. Varges's examples of wallconstruction around towns all belong to a comparative late period.*

As to trade, it is certainly worth observing that in many charters the right is granted in very general terms, without limitation to markets or particular days. $f$ Dr. Varges has done well to point this out; and the whole subject of mediæval trading usages requires fresh investigation. But it may be asked whether, apart from the

* Writers who have dwelt on the connection of Burg with fortification have not noticed the doubt cast upon it by the use of bourg, clearly the same word, in French. Bourg is popularly used in many parts of France, especially in the centre and in Normandy, for "toute agglomération d'habitations ayant un clocher, fût-elle reduite à un très petit nombre de maisons," Jaubert, Glossaire du Centre de la France, with an apt quotation from G. Sand's Valentine. The dictionary-makers, however, define it as "Gros" (Littré, "Grand ") " village, où l'on tient marché," Dictionnaire de l'Académie; to which the Academy adds, "ordinairement entouré de murailles." The word was early connected by philologers with the Greek $\pi v$ pyos and the German Burg; and this raised the question whether it implied the presence of fortifications. Thus the Dictionnaire de Trevoux (1743), after defining Bourg as "ville non close; habitation de peuple qui tient le milieu entre la ville et le village," adds, "Quelques-uns le restreignent aux lieux qui ne sont fermés ni de murs ni de fossés. D'autres, au contraire, comme messieurs de l'Académie veulent que se soit un gros village, fermé de petites murailles." Certainly, as applied to a settlement outside a cité, it always suggested the absence of walls. See above, p. 372 , note.

†Thus in the charter to Magdeburg (1201-38), "Quilibet burgensis, aut propriam habens aream vel domum, quarumcunque rerum venalitatem habuerit, eas in domo propria libere vendere potest, ant pro aliis rebus commutare." But it must be noticed that this is comparatively late in town history. It does not follow that the grant of a market may not have had great importance in an earlier century. 
sale of food, trade was not, as a matter of fact, usually carried on in markets and fairs; whether we can suppose that the sale of food by one neighbor to another ever really required permission by charter; whether the benevolence of the grant of trading rights on the lord's part and the value of it to the recipient did not lie in the permission it gave to levy tolls on the frequenters of the market, and especially on outsiders. As to the term mercatus, Dr. Varges's attempt to free it from association with the market is rendered the more difficult by the fact, to which he does not refer, that in classical Latinity it meant a market-place or mart (among other things), and never trade in the abstract. Some of the earliest charters, also, use verbs in conjunction with mercatus, which are most naturally interpreted in the more limited sense.* Moreover, he weakens his argument by constantly bracketing together Wochenmarkt and Jahrmarkt, market and fair, as if their functions were much the same. The fair involved, as it seems to me, a temporary suspension of the economic system of the town, while the market was an ordinary part of it.

V.

The articles of M. Pirenne, next in order, combine, as we might expect from a Belgian writer with a German training, the merits of both German and French methods of exposition. Like Dr. Varges, he takes pains with the arrangement of his material; but, fortunately, he also resembles $M$. Flach in aiming at a certain elegance of presentation.

* "Mercatum erigere," Charter to the Abbey of Quedlinburg, 993. "Licentiam construendi mercatum," to the Archbishop of Bremen, 1003. "Mercatum vero constituat publicum in illis ubicunque abbati placuerit locis," Charter to the Abbey of Corvey, 946. Cf. "Mercatum constituimus in Burch, ut nullum aliud habeatur inter Stanfordiam et Huntenden," Charter of Edgar of England to the Abbey of Peterborough. 
M. Pirenne begins by following M. Flach in his account of the fortunes of the Roman cities in the Dark Ages. They survived, in a sense, huddled up in a corner of their old site; but all the old municipal life died out. Such activity as was still to be seen was usually that of some ecclesiastical establishment, most commonly of a bishop and his ministeriales. Meanwhile, in the country around, freedom had disappeared: the whole land was broken up into seigneurial domains, tilled by serfs of various degrees. Trade ceased: the western world "entered on the agricultural period of the Middle Ages." Town life was no longer urban: the town was now only a place of "religion," and the centre for the administration of great domains. And this was roughly true of all the more important ancient towns, in spite of the facts that some towns, relatively few in number, were the residences of lay, and not of ecelesiastical, lords; that a public jurisdiction survived, in theory at least, by the side of manorial; and that no town altogether escaped "the law of dispersion." The town, in its later legal sense, did not yet exist.

The great change came with the rise of trade in the eleventh century, and the formation in various places of groups of merchants and artisans. The idea that these men were, in any important sense, brought together by the prior existence at such places of any such local attraction as a religious house, a castle, or a market, $\mathrm{M}$. Pirenne brushes aside. He declares that these aggregations were due to "purely natural causes." They are to be explained not by history, but by geography. As trade grew up, points of vantage were fixed upon as places of residence, precisely as we see them being occupied in new countries to-day. True, most of these places were upon the sites of old Roman towns; but this was only because those sites were favorably situated for trade, especially such of them as were at the points of intersection of old Roman roads. A new economic period opened: trade 
takes its place by the side of agriculture, and "the towns are the work of the merchants."

To explain the position of affairs, M. Pirenne turns aside to sketch the previous history of the merchant class. The trader, as he first makes his appearance in the Carlovingian age, whether man of wealth or petty pedler, is " essentially a wandering being, passing continually from place to place, and both protected and exploited by the sovereign." The same is true after the restoration of order in Germany by the Saxon kings. Still, wanderers as they were, they must have had resting-places for the winter; not to mention homes for their families, - a necessity which M. Pirenne overlooks. Accordingly, settlements of merchants began to be seen at convenient places. But, as elready explained, such sites were already partially occupied "by the towns of the agricultural age"; and so now beneath the old walls grew up the faubourg, the Vorburg, with its trading population. The faubourg is the starting-point of the town of the new era. Here is to be found the market; and the primitive burgher-body is not composed of ministeriales or of emancipated serfs, but of a group of settled traders. $\dagger$ The land upon which they built their homes might be subject in all sorts of ways to all sorts of lords: they themselves were of diverse origins and of every degree of opulence. But economic forces were working towards the creation of a uniform status; and they were aided by certain contemporary practices. In the first place, merchants had from early times been taken under royal protection, resulting, as $\mathbf{M}$.

* "Les villes sont l'œuvre des marchands; elles n'existent que par eux. Romaines ou non-romaines d'origine, siège d'un évêché, d'un monastère, ou d'un château, libres ou soumises au droit domanial, elles ne commencent a acquérir une constitution municipale que du jour où, à côté de leur population primitive, vient se fixer une outre population, vivant essentiellement de commerce et d'industrie." Revue Historique, lvii. 70.

$\dagger$ "Ce fanbourg, point de départ de la ville nouvelle," etc. "C'est des marchands que se compose la bourgeoisie primitive." Ibid., 74 . 
Pirenne understands it, in their retention beneath the jurisdiction of the public courts, not, as other writers have it, in their subjection to a special royal jurisdiction apart from the public courts. The right to demand toll from traders was also a royal right; and, where inferior lords exercised it, it was always in virtue of a royal grant. Accordingly, the traders all remained under the same jurisdiction, and that a public one. Yet, as the persons who exercised it were only too likely to misuse their powers, and the traders as isolated immigrants were devoid of the support of kindred, they were obliged to combine; and so we account for merchant gilds, hanses, charities, and like associations. These associations may very well have had their first beginnings in the mutual help, the subordination to chosen leaders, necessary in the bands or "caravans" in which during early times traders were obliged to travel for the sake of security.*

Then follows what we may regard as a combination of the theory of Nitzsch with the traditional French view, modified somewhat in deference perhaps to Hegel and Gross, though scant regard had been paid to their opinion as to the non-identity of merchant and burgher. .The merchant gild formed at first "a vast association," including all who had anything to sell. Not till later did it become exclusive; and this was due partly to increasing wealth and the growth of a spirit of monopoly among the richer members, partly to the "entire absorption of the artisan by industry" proper (as distinguished from trade). The craftsmen became wage-laborers, and ceased to have any need themselves to sell their produce. The gild in many towns secured a considerable jurisdiction in matters eco-

*This idea and the not very appropriate term "caravan" first appear, I believe, in an article by Lamprecht in the Historische Zeitschrift, lxvii.; and they are repeated in his Deutsche Geschichte, iii. (1893) 27 et seq. Thus Lamprecht lays down the proposition that " der temporären Form der Kauffahrtgilde war die stetige der Platzgilde gefolgt." The view is not in itself improbable; but M. Pirenne would have done well to pay more attention to ron Below's amusing criticism in Ursprung, 135 et seq. 
nomic, and controlled the market: it sometimes contributed out of its funds to common town purposes. Yet it remained a voluntary society; and, while it helped in the development of town institutions, it did not create them. Its deacons (aldermen) did not become town magistrates, nor its regulations town-law. Association gave the merchants the strength required to enable them so to transform old institutions as to create the town: it did not furnish the mould into which the new constitution should run. This is illustrated by the history of the jus mercatorum, which appears in the eleventh century, and becomes one of the sources of later town-law. The jus mercatorum is not the handiwork of the gild, though the gild helped to spread and maintain it. It is simply a modification of the old common law under the pressure of the peculiar needs of traders. Accordingly, it is not peculiar to any particular country or town, but, in a sense, international.

Up to this point what we have seen has been the settlement of a new group, the traders, by the side of the old groups of ministeriales and serfs already to be found. The next question is, how did the personal privileges of the merchants become attached to the soil? Here the key is again found in economic pressure. This first made the trader personally free; then freed the soil, and created the tenure known as bourgage (French), burgage (English), Leihe zu Burgrecht (German); then gave freedom from arbitrary toll in return for an annual rent paid to the lord; then brought about the establishment of a new tribunal, composed of burghers, to administer the new law. But by this time all the other groups living alongside of the traders wished to enjoy the same advantages; and out of the chaos of struggle arose, at last, the new unity, the all-embracing community. What were the chief factors in this last stage of its history?

By a new road we come once more to the town-peace. 
All are agreed that mediæval towns, in France as in Germany, were under such a speciât peace. Büt its origin M. Pirenne attributes neither to the peace of God nor to the peace of the market, nor to the protection enjoyed in an earlier age by merchants . as individuals, ${ }^{*}$ but, as before, simply to the constraining force of new conditions. The towns were the resorts of all sorts of shady characters; and the only way to secure anything like order was to establish a permanent "state of siege." That is what the town-peace was, - an exceptionally severe criminal code; and it was the feeling of the need of such a Draconian code which led the townsmen to seek for the grant of a peace from their lord. The limits thereof were the city wall, which now began to be everywhere constructed to enclose the faubourg. The space it contained did not necessarily correspond to any previous territorial division, public or private: it was determined by economic causes alone. To secure the peace had needed a common movement of the population, and an oath of mutual support, a conjuratio: union was also required to secure exemption from seigneurial claims; and a joint contribution had been necessary for the building of the wall. And so, in all these ways, under the pressure of a triple necessity, the commune gradually became conscious of itself.

The urban tribunal was, in like manner, the direct consequence of the novel requirements of the situation. It was, indeed, a public court; and it succeeded to the ancient court of the centena (or "hundred"). $\dagger$ Still, it has a specifically urban character: it is composed of burgesses, it is more or less chosen by burgesses. And, as it is not a

* Referring to a supposed Kaufleutesonderrecht, on which emphasis has been laid by many writers, notably Inama-Sternegg and Gothein. For an account of their views see Doren, Untersuchungen zur Geschichte der Kiaufmannsgilden des Mittelalters (1893), 25 et seq.

† "Maire, écoutète, avoué, le juge urbain, est le successeur incontestable de l'ancien centenier frane" (Revue Historique, lvii. 308); though the precise meaning of the remark is not free from doubt. 
mere market-court in its origin, so it is not a mere survival and transformation of the court of the centena. It is a new creation, the necessary consequence of the recognition of the principle that the burgesses have a right to be judged in their own town by the customs there established; and the law it enforces is, on one side, the civil law which grew out of the jus mercatorum, and, on the other, the criminal law born of the town-peace.

Finally, the town council is, again, no mere survival or transformation of an old institution. It is a "college of delegates" acting on behalf of the bourgeoisie, such as was sure to appear as soon as the bourgeoisie became aware of itself. It may be called an executive committee of the burgher body.

The internal movement by which, within the now united burgher body, a separation arose between the rich and the poor, the majores and minores, and an oligarchical government was established,- ruling in economic matters through the machinery of the merchant gild,- belongs to a later period.

Up to the point now reached, the thirteenth century, the development had been roughly parallel, with local variations, over the whole of the country between the Elbe and the Seine. Not till now did the lines of evolution begin to diverge; and the divergence was due not to differences of race, but to the difference between France and Germany in the strength of the central authority.

M. Pirenne's whole theory, it will be seen, turns on the "colony of traders"* which made its appearance at the old Roman town, and on the formation of the association which "was for them a primordial necessity." $\dagger$ The merchant-body first secured rights for itself, and then brought about their extension to that older agglomeration of population by whose side it had settled. This is none

* "Les colonies marchandes." Revue Historique, lvii. 75. † Ibid., 81. 
other than the Kaufmannsgemeinde, which had already been made the all-important factor in town development by a succession of German writers.* What is original in M. Pirenne's exposition would seem to be his freeing the influence of the merchant-community from any necessary dependence on market-privileges. But it suffers from the same weakness as the theory in its German garb; namely, a failure adequately to account for the extension of traders" rights to "the divers social and juridical groups which coexisted with them." $\dagger$ The motives which are supposed to have led to the establishment of the peace, to the construction of a wall (or rather l'enceinte $d u$ faubourg), and to the acquisition of franchises, were all motives primarily affecting the traders ; and, if they could but secure these advantages for themselves, there was hardly any strong reason for desiring to extend them to others.

I cannot help thinking that the light-heartedness with which M. Pirenne has passed over this very real difficulty is due to some vagueness in his own mind as to the situation of these earlier groups. Like M. Flach, and like the recent German writers who have described the Römerstädte, M. Pirenne begins by thinking of "the cities of the agricultural period" as themselves walled. $f$ In this view the faubourg was outside the walls, outside la ville.§

* "Die Entstehung einer Kaufmannsgemeinde, eines Kaufleutegerichts, und eines besonderen Gerichtsbezirk, d.h. der Immunität vom Landrechtsverband, das sind die Grundbedingungen für die Entstehung der deutschen Stïdte, soweit dieselben Kaufmanns- und Marktstädte sind, d.h. dem Handel ihre Entstehung verdanken. Derartige Kaufmannsgemeinden lassen sich nun in vielen Städten Deutschlands noch positiv nachgewiesen; vor allem hat der Aufsatz Schultes sie wieder in den Vordergrund des Interesses gerückt. Sie siedeln sich in den alten Römerstädten meist vor den Thoren der alten Stadtmauer an. Wir wissen von solchen Kaufmannsgemeinden, z. B. in Köln, Regensburg, Worms, Mainz, Basel, in Goslar, Magdeburg, und Quedlinburg." Doren, Untersuchungen, 34 .

$\dagger$ Revue Historique, lvii. 97.

$\ddagger$ Ibid., 60. Cf. the "murs" and "portes" of p. 64 .

§In the sense of p. 62. 
What, then, it would be necessary to do later would be to push out the town wall so as to include the faubourg, or, what came to the same thing, to build an additional wall as a loop round the faubourg. But, when M. Pirenne gets further in his exposition, the town to which the "colony" joins itself - that which we may call, accepting for the time M. Pirenne's general theory, "the pre-commercial datum"- becomes merely a "château et immunités." * The new settlement now takes place "in the town." $\dagger$ Still more surprising, the enceinte $d u$ faubourg is not now described as an addition to a previously existing town wall; but, starting from and returning to the "château seigneurial," it is the "enceinte," the "mur," "de la ville" itself. $\neq$ Henceforth it is argued about as if it were the first wall the town ever had.\$

I am, of course, far from maintaining that the precommercial datum was really always a walled town. In many cases, in all probability, it was simply a castle, in the modern sense, with an unenclosed cluster of cabins at its foot, as M. Flach has pointed out. But it is surely worth while to pause from time to time, and consider which we are to keep in our mind's eye. We can only arrive at results satisfactory to the social historian by determining to visualize the process we imagine at work; and this we cannot do so long as the centre of the picture remains in mist.

*"Une urbs nova, un suburbium, un faubourg commercial, se forme a côte du château et des immunités, dont l'ensemble constitue la ville de l'âge agricole." (p. 74.)

$\dagger$ Page 75.

$\ddagger$ Page 299 .

$\S \mathrm{M}$. Pirenne speaks of the suburbium as built "sons les murs du castrum primitif," echoing the language of M. Flach. But, while M. Pirenne gives the impression, in this latter part of his argument, that the castrum was simply a lord's eastle, M. Flach, as we have seen, carefully distinguishes between that narrower sense and the wider sense in which it was used for a fortified town area. See supra, pp. 371, 372 . 


\section{VI.}

We have now come to the last work upon our list, Dr. Keutgen's Untersuchungen, a work, it must be remembered, strictly, and on principle, confined to Germany. It is one that may well be placed by the side of M. Pirenne's for its skilful arrangement of material and its subordination of detail to generalization.

In his introduction Dr. Keutgen points out, what is often forgotten or denied, that the only classification of towns of any use for the present purpose must be a chronological one. German towns he divides into three groups : (1) the bishops' towns on the Rhine and Danube, of Roman origin; (2) towns springing up in inner Germany, from the ninth century onwards, - whether beside an episcopal or royal household or otherwise, it matters little; (3) artificial foundations, from the end of the eleventh century, on which was bestowed an already-constructed town-law. But this is a classification to which Dr. Keutgen pays little attention in the rest of the treatise. His chief conclusions are conveniently given at the end of this same introduction. Two main lines of development, he says, have to be kept apart, and considered separately,the origin of the urban tribunal, and the origin of the organization of the urban community itself. "The German towns formed, in the Middle Ages, separate districts (Bezirke) of the public judicial organization; and the organization of these public courts corresponds (entspricht) to that of the public courts in the country at large (auf dem Lande)." The town, however, had sometimes no voice, and often but little voice, in the actual appointment of the judges. "As to the urban community, the question is" simply "how the constitution which every German local community (Ortsgemeinde) possessed from the first, by virtue of its autonomy in certain matters, 
followed a peculiar line of development in the towns, and ended in the establishment of the council."*

With regard to the town tribunal, Dr. Keutgen abides by the old explanation which traces it back to the centena, the hundred court. He thinks that, as a rule, by the tenth century the towns had come to form separate jurisdictional districts, and that these were not simply like hundreds, but actually were small hundreds. The Ottonian privileges put them into the hands of the bishops, (or, to use a phraseology familiar to students of English constitutional history, made them "dependent hundreds"). As against Arnold and von Below, Dr. Keutgen has no difficulty in showing that the grants of the Ottos did apply to specifically urban areas. In this town-court, however, there was at first no special town-law administered. To explain the growth of a special town-law, and the legal (as distinct from the political) reasons for a separate towncourt, Dr. Keutgen proceeds to consider the town as a place of defence (die Stadt als Burg). In much the same way as von Maurer and Dr. Varges, he points out that Burg was the oldest German name for town; and he remarks on the survival of borough as the technical designation in England. He calls special attention - and this was well worth doing - to the peculiar importance of the Burgen established in Saxony by King Henry. Though by no means all of them became real towns, the earliest towns that did arise in inner Germany grew up at some of the points so marked. Having thus prepared the way, he suggests tentatively that the position of the town as a place of defence may have had important legal consequences. We seem to be approaching Dr. Varges's elt garrison-theory. But no! Dr. Keutgen's view is really more akin to that of Sohm. Everything connected with the king was, in early times, under a special peace. The Burg as a fortress (really, not constructively) was itself

\footnotetext{
* Untersuchungen, 9.
} 
the king's in theory, if not in fact: hence it was subject to the special king's peace; and hence the Burgfriede.

Passing over Dr. Keutgen's elaborate criticism of the market-theory, which is very effective, we reach the civic community. This, as before indicated, our author regards as merely an outgrowth from an Ortsgemeinde. Here he is in substantial agreement with von Maurer and von Below. Indeed, he may be regarded, on this side of the subject, as a pupil of von Below. Like him, he objects to von Maurer's terminology, chiefly because it lays, as they think, undue stress on one feature,-communal management of land, without proper regard to other communal powers.*

Burgess-rights, as might be expected in towns with such an origin, were bound up with the possession of land, and had nothing necessarily to do with mercantile pursuits. We may omit the long and interesting, but hardly convincing, argument as to the origin of die städtische Erbleihe, Leihe zu Stadtrecht, zu Burgrecht (i.e., burgage), and reach the concluding chapters. Here Dr. Keutgen comes so far to meet the market theorists as to assign great importance to the settlement (Ansiedelung) of traders in various places. Without them, no town. He accepts a special jurisdiction of the merchants over matters specially concerning themselves. As to weight and measure,-concerning which there has been an acrid dispute,-Dr Keutgen takes the middle position that the commune ( $G e$ meinde) controlled the weights and measures of articles of every-day use, the merchants those of commodities wherein they especially traded. Out of a union of the township and the market the later town grew. Into the

* Page 109: "Die Dorfverfassung beruhte nieht, oder doch nur äusserlich, auf der Markgemeinschaft, sondern sie beruhte auf dem Selbstbestimmungsrecht der Gemeinde wirthschaftlich selbständiger Männer." Cf. p. 110: "Wie die Gerichtsverfassung der Stadt auf dem Boden der allgemeinen öffentlichen Gerichtsverfassung steht, so beruht anch die Verfassung der Stadtgemeinde durchaus auf den Grundlagen der allgemeinen deutschen autonomen Gemeindeverfassung." 
stages of the process he does not enter at any length.* Like M. Pirenne, the council he regards as a mere committee (eine Art Ausschuss) of the burgher body which was formed by the union of these two elements.

Dr. Keutgen's most original contribution to the discussion is his theory of Burgbann. But this, it must be observed, he leaves a mere conjecture. He himself recognizes that the earlier uses of the term Burgbann are to be explained by the right of the Burggraf or some similar official to compel the residents of the environs to work at the repair of the walls. But he thinks that some confirmation of his theory is to be found in four documents of $1095,1014,1024,1101 . \dagger$ The first and third make a fine of sixty shillings payable for the breach of Burgbann; the second limits the imposition of a fine of this amount to publica civitates; the fourth calls it jus civile. But none of these necessarily connect the peace of the town with a fortress peace of the king. By this time Burgbann might very well have meant nothing but town-law.

As to the Ortsgemeinde, it is curious to observe how Dr. Keutgen (in this respect again following von Below) assumes his major premise. The Landgemeinde was "autonomous," "self-determining," and had such and such Befugnisse (competence). The town-community was likewise autonomous, and had a like competence. Therefore, the town-community could have been nothing originally but a Landgemeinde. But, if - putting on one side the whole question of serfdom and relation to a lord - we look up the examples of the competence of the Landgemeinde $(e . g .$, in the matter of protection against fire, building reg-

* Page 218: "Man sieht wie in einer aus Dorf- und Markt-ansiedelung zusammengewachsenen Stadtgemeinde die gewöhnheitsrechtlichen Befugnisse der Kaufleute zu den ähnlichen der autonomen Landgemeinde hinzu kamen, um zusammen den Ursprung der stadtischen Verwaltungsthätigkeit zu bilden."

† Page 57 et seq. 
ulations, etc.), for which Dr. Keutgen refers to von Maurer, we find that they are all drawn from Weisthümer (records of custom) of the sixteenth, seventeenth, eighteenth, and even nineteenth centuries.* From what one knows of village life one may be pretty sure that such powers were not exercised in the Middle Ages. There can hardly be a doubt that these Befugnisse of the Landgemeinde were belated imitations of town practices, and not their source. $f$

\section{VII.}

The reader who shall have made his way through the preceding abstracts will probably experience a feeling of bewilderment, for which he may be inclined to blame the writer. It would, no doubt, have been possible to arrange an account of the recent literature of the subject in a different manner,- to present the chief proposed solutions of the main problems involved, and state the attitude of the various writers to each in a form admitting of easier comparison. But such a presentation would have given little idea of the way in which each writer really approached the subject. The differences in emphasis, the differences in the number and grouping of the several factors recognized, are at least as interesting as positive statements, when we have to do with essays in construction all more or less eclectic in their character.

It would be rash to attempt to judge between the rival theories thus offered to the inquiring economist by historians and lawyers. The battle must be fought out by the specialists themselves. Yet there are some fundamental

* Maurer, Geschichte der Dorfverfassung, ii. 11 et seq.

$\dagger$ Since writing the above, I have noticed the remark of Schröder, Deutsche Rechtsgeschichte (2d ed.), 603: "Die politische Befugnisse der Landgemeinden waren zu spärlich und sind wohl auch zu spät zur Anerkennung gelangt, als dass sie schon bei der Ausbildung der ältesten Stadtverfassungen haitten in Gewicht fallen können." 
questions which even an outsider may press upon the attention of those immediately engaged in the discussion.

First, then, as to the Landgemeinde, the Ortsgemeinde, the rural township or village. That many towns grew out of villages, the agricultural character of the interests of the smaller towns of the Middle Ages and the survival of agricultural usages and manorial burdens similar to those on rural manors, would seem clearly enough to indicate. But why should we suppose all towns to have so arisen? Make the breach between the Roman and the mediæval world as great as we please, is it not allowable to think of the majority of the inhabitants of the "old cities" of M. Flach, the Römerstädte of the German writers, as all along different in their daily occupations from the men of a country manor? And, limiting our attention to those towns which did spring from rural townships or combinations of townships, the question ought to be faced whether there is any positive evidence at all for the existence of free, "autonomous," "selfdetermining" townships in the period of the rise of the towns. Accept, if you will, the view that the lord was a comparatively recent usurper: still, there he was at that time. And, if so, is it well so completely to disregard him as such writers as von Below and Varges and Keutgen in effect do? But, if he is to be counted with, then the difference between the Landgemeinde view and the Hof-system theory of Nitzsch need not be so very great, after all. The difference would then simply resolve itself into this: that Nitzsch had in his mind the great masses of dependants, most of them not engaged in agriculture, at the large seigneurial establishments, while with the Landgemeinde we begin with a small body of dependants, all of them engaged in agriculture, on a rural estate.*

* $C f$. my review of von Below's Ursprung in the Economic Journal, vol. iv. p. 272 . 
The other part of the subject on which an economist might venture to dwell is the much-vexed question of the relation of the "merchant" to the "craftsman," with which is closely connected the doubt as to the original meaning of mercator and Kaufmann. Concerning the significance of these terms there is an amusing difference of opinion. Some understand thereby any one who ever had any occasion to buy and sell in a town,* or, indeed, all who had the right to buy and sell,--i.e., all the townsfolk, - which is thought to be confirmed by the use of "mercatores" and "burgenses" as synonymous in many early charters. Others regard the "mercator" as a professional trader, like the trader of to-day,- though his operations might frequently be very small,- and explain the use of mercatores, negotiatores, institores, for burgenses, as the result of their prominence and their peculiar association with town life. It must be said that the particular bit of evidence which now seems to lead many scholars to accept the widest possible interpretation is singularly weak for such a superstructure. In a charter granted by the abbot of Reichenau to the peasants of Allensbach in 1075 occurs the phrase, "Omnibus oppidi villanis mercandi potestatem concessimus, ut ipsi et eorum posteri sint mercatores." This is usually interpreted to mean that the grant in some sense or other actually turned the villani into mercatores. But why can we not regard it as the expression of a hope? Dr. Keutgen well points to definitions such as "mercatores qui causa negotiandi vadunt et redeunt" $\dagger$ as showing that "merchants" were distinguished

*Bücher in his Entstehung der Volkswirthschaft, 47, note, is particularly wroth with those who would make mercator into a "Berufs-Kaufmann." He understands thereby "jeder der mit seiner Waare zu Markte stand." Indeed, his etymological observation - "Das hervorstechendste Merkmal des BerufsKaufmanns in seiner Verhältniss zum Pnblicum ist nioht seine Gewohnheit zll kaufen sondern zu verkaufen. Und doch ist der mittelälterliche 'Kaufmann' nach dem Kaufen benannt!"- would seem to extend the designation to any one who ever bought anything. It is a pity he cannot propose a like etymological interpretation of "mercator."

†Untersuchungen, 190, note. 
from persons who stayed at home and occasionally sold their own produce. Moreover, no one seems to deny that the "mercator" of Carlovingian times was a wandering professional trader; and it would be strange, indeed, if the word afterwards underwent so complete a change of meaning as to rob it of almost all economic significance.

Whatever else they may think of the meaning of mercatores, most writers have no difficulty in believing that at first it included craftsmen. Suppose we allow that it included all who had frequent occasion to buy and sell. Did the earliest craftsmen have occasion to buy and sell? M. Pirenne, as we have seen, thinks they did; that later they became mere wage-earners, and then ceased to buy materials or sell finished goods, and so needed no longer to belong to the merchant gild. It must be confessed that there is something in the economic condition of M. Pirenne's country - Flanders - in the fourteenth century to lend some color to this explanation. The crowds of weavers and fullers and dyers of Ghent have always seemed rather hard to fit into "the gild system" framework. But elsewhere, surely, the movement of things was just the reverse of what $M$. Pirenne supposes. The latest investigations into mediæval industry are rendering it clear that the mediæval craftsman worked at first on the materials of an individual customer, often at the customer's own house. Down to the close of the Middle Ages scores of craftsmen never bought materials or had wares to sell; e.g., those engaged in various branches of the building trades. Nevertheless, after a time many, if not most, craftsmen did come to manufacture wares for the general market out of their own materials. That this produced friction with the merchant-gild, both in England and Scotland, we have good reason for believing, and the play of economic forces on the continent could hardly have been essentially different. May not the key to some difficulties in mediæval economic, and therefore in 
mediæval constitutional, history be found in the probability that it was only as and when craftsmen desired to dispense with intermediaries in their buying and selling that any antagonism would arise between merchants and craftsmen as such?

Reviewing the discussion as a whole, with all its finedrawn distinctions, the economist will perhaps arrive at the paradoxical conclusion that what is first of all necessary is that distinctions should still further be drawn, and one in particular. It is one of the chief services of von Below that he has impressed upon us the necessity of separating the question of the forces which led to constitutional change - one often of economic history - from the question of the structure and derivation of the constitutional forms themselves, which is one of legal or constitutional history.* But we must go further, and distinguish provisionally between the town (Stadt, ville) as a legal conception and the town as an economic conception. Usually, the two meet. What was economically a town was, as a rule, legally (or constitutionally) a town. But it was not necessarily nor universally so. And the discussion on both issues really turns, in large measure, on a question of definition. What shall we agree to call a "town" economically, what constitutionally? Until we have come to some common understanding on these points, there is always the danger of arguing in a circle.

These preliminary notions having been cleared up, the work of historical construction can safely begin. And in this, in spite of the example to the contrary of all the four scholars we have here been following, the path of safety would seem to lie in a rigid observance of chronological limitations. To leap, as some writers do, from a document of A.D. 900 to one of A.D. 1350 is certainly

* Stadtverfassung, 12. Von Below hardly, perhaps, recognizes that, while this distinetion is useful, and indeed essential for clearness of thought, the answer to the one question has commonly a very direct bearing on the answer to the other. 
dangerous. Not that there is no weight in the argument that the conditions within small towns in later times must have resembled those, centuries before, in what afterwards became great towns, because "every town was once small." * It is very probable that there was something like a natural evolution of town life, whereof the early stages are concealed from us, in the case of the greater towns, by our lack of evidence, but fully revealed in the later and smaller. Yet it is clear that the men of later centuries must have lived in an atmosphere of ideas to which the earlier development of the larger towns had already given rise, and these ideas must have influenced their action. Until, then, the main lines of the earlier history have been retraced from contemporary sources, it will be wise to observe a self-denying ordinance in the matter of using later documents.

*Von Below, Stadtverfassung, 4 ; Stadtgemeinde, 114. 

ALL BOOKS ARE SUBJECT TO RECALL RENEW BOOKS BY CALLING $\underline{642-3405}$

\section{DUE AS STAMPED BELOW}

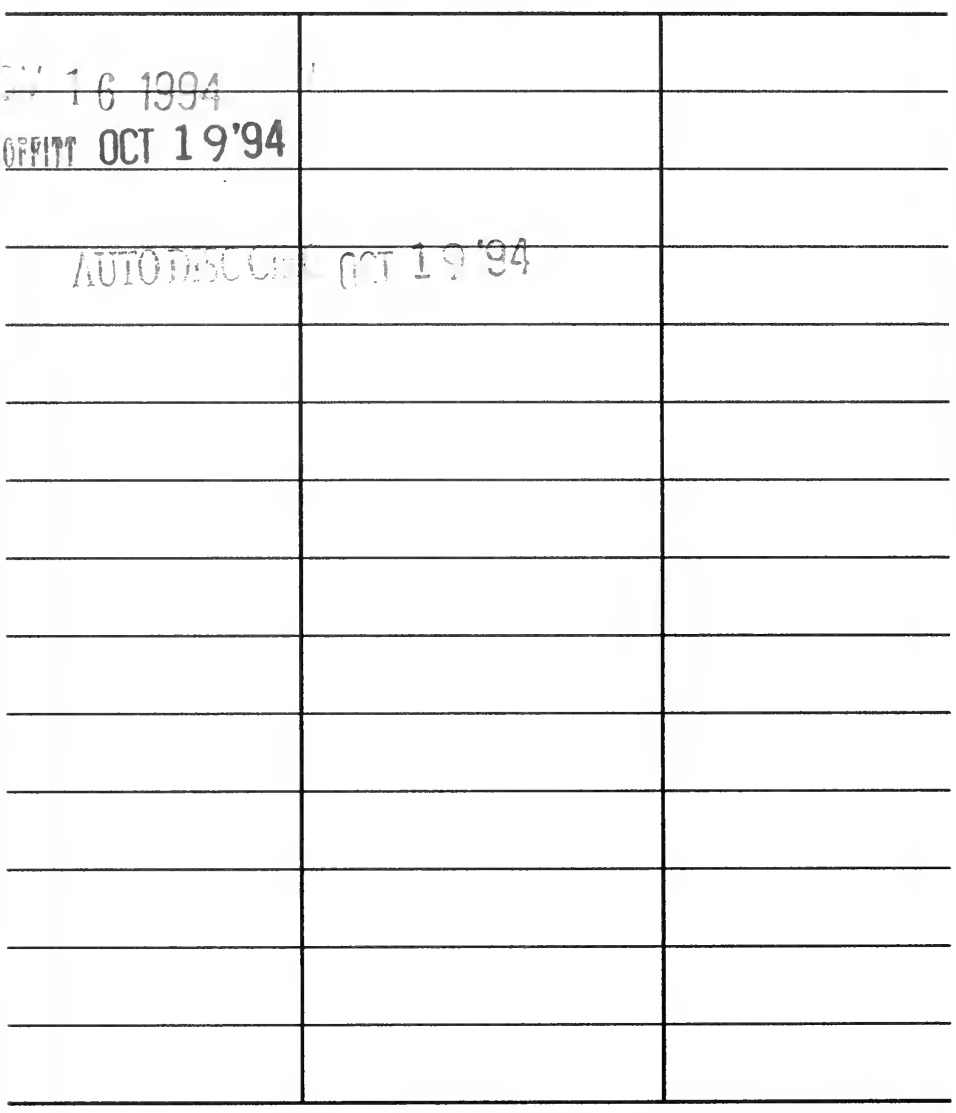

UNIVERSITY OF CALLFORNIA, BERKELEY

FORM NO. DD6 BERKELEY, CA 94720 

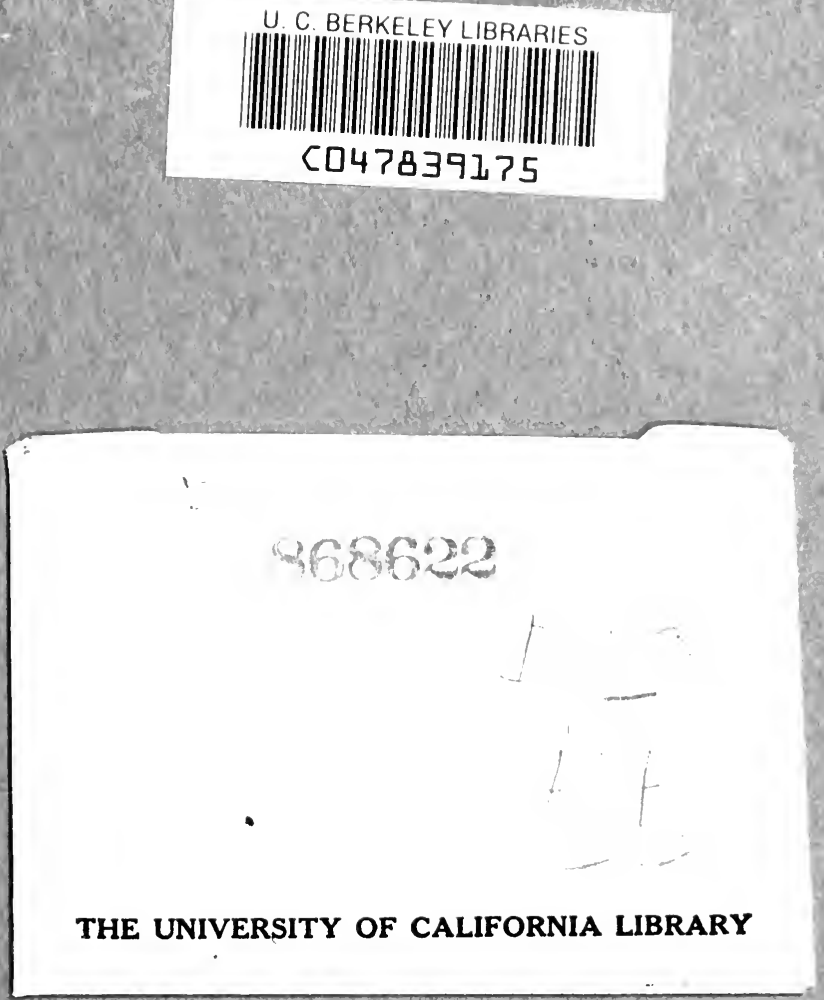
